\section{Retoryka deratyzacji w PRL: od czystki etnicznej i politycznej do czystki gatunkowej}

Gabriela Jarzębowska

TEKSTY DRUGIE 2018, NR 2, S. 120-137

DOI: $10.18318 /$ td.2018.2.8

$\mathbf{W}$ niniejszym tekście przyglądam się retoryce towarzyszącej praktykom tępienia szczurów w Polsce w latach 1945-1989 i je kształtującej oraz rozwijam na ich podstawie pojęcie czystki gatunkowej'. Sprzężenie mechanizmów nowoczesności (wraz z towarzyszącymi jej metaforami oczyszczania) z narracją militarystyczną bazującą na deprecjacji wroga jest powszechnie rozpo-

1 Artykuł jest efektem badań archiwalnych związanych z przygotowywaną dysertacją doktorską, opartych na kwerendzie w Archiwum Akt Nowych, Archiwum Państwowym w Łodzi, Archiwum Państwowym w Szczecinie, Bibliotece Narodowej, Muzeum Dezynfekcji, Dezynsekcji i Deratyzacji oraz Muzeum Plakatu w Wilanowie. W moich badaniach poddałam analizie ikonograficznej i semiotycznej materiały propagandowe poświęcone szczurom i deratyzacji pochodzące z lat 1945-1989 (plakaty, ulotki, odezwy, publikacje fachowe, audycje radiowe, dokumenty). Samych analiz nie prezentuję w niniejszym tekście z uwagi na jego ograniczenia objętościowe. Wartykule przedstawiam zatem wnioski i konceptualizacje wypływające $z$ analiz źródeł historycznych i próbuję wpisać owe wnioski w szerszy kontekst kulturowy.
Projekt Czystka gatunkowa. Polityczny wymiar tępienia szczurów po 1945 roku zostałsfinansowany przez Narodowe Centrum Nauki w ramach konkursu Preludium, na postawie wniosku 2017/27/N/HS3/00013.

\section{Gabriela}

Jarzębowska - doktorantka na Wydziale Artes Liberales UW, stypendystka Uniwersytetu w Linköping i Polsko-Amerykańskiej Fundacji Fulbrighta. Zajmuje się humanistyką środowiskową oraz krytycznymi studiami nad zwierzętami. Przygotowuje doktorat pod kierunkiem prof. Ewy Domańskiej i prof. Andrzeja Elżanowskiego. Publikowała m.in. w czasopismach "Maska”, „Wakat"i „Praktyka teoretyczna". 
znane na gruncie studiów nad ludobójstwem, zwłaszcza nad Holokaustem. Moje badania wykazują, że podobny mechanizm można zaobserwować w debacie związanej z zarządzaniem środowiskiem. Zwierzę mające ugruntowany niski status kulturowy zostaje w jego ramach wpisane w narrację sanitarną i stygmatyzowane jako niebezpieczny wróg. Tradycyjny status szczura jako szkodnika, stanowiący kulturowo-mentalną podbudowę i warunek wstępny dla szeroko zakrojonych akcji jego tępienia, w latach powojennych zyskał bowiem wzmocnienie ze strony dwóch dyskursów kształtujących ówczesną debatę publiczną. Jeden z nich stanowił dyskurs militarystyczny, będący z jednej strony pokłosiem wojny i, co za tym idzie, militaryzacji języka dyskusji publicznej, z drugiej zaś - specyficzną cechą retoryki czasów stalinowskich, zasadzającej się na aktywnym poszukiwaniu i tępieniu prawdziwych lub wyobrażonych przeciwników. Drugi dyskurs organizujący retorykę tępienia szczurów w tym okresie to dyskurs sanitarno-epidemiologiczny, w ramach którego zostało wykształcone pojęcie DDD (dezynfekcja, dezynsekcja, deratyzacja). Narracje te stanowiły odrębne (i charakteryzujące się często zróżnicowaną frazeologią), ale wyraźnie komplementarne składowe kulturowego obrazu szczura w tej epoce.

Celem artykułu jest analiza mechanizmów, za pomocą których zwierzęta były włączane do narracji politycznych w kontekście procesów nowoczesności. Proponuję tym samym alternatywne, gdyż bazujące na biologiczności, spojrzenie na retorykę modernizacyjną w PRL. Umocowuję zarazem uzyskaną wiedzę w szerszym kontekście historyczno-kulturowym, rozpoznając ciągłość wzorców językowych i ikonograficznych, jakimi opisywane były szczury w tym okresie. Udowadniam, że schematy przedstawienia tego zwierzęcia wyraźnie bazowały na wypracowanej wcześniej retoryce związanej z deprecjacją przeciwnika w programach czystek etnicznych i politycznych. Celem moich badań jest zatem zmapowanie możliwych metastrategii wspólnych dla etnicznych i politycznych czystek oraz niektórych form zarządzania środowiskiem. Podejmuję także próbę zdefiniowania pojęcia czystki gatunkowej i wpisania jej w szerszy kontekst, związany z procesami konstytuowania nowoczesności.

Artykuł należy rozpatrywać w kontekście „zwrotu biologicznego” w historii i humanistyce w ogóle², którego konsekwencją jest rosnące

2 Por. D. Wężowicz-Ziółkowska, E. Wieczorkowska Biological turn. Idee biologii w humanistyce współczesnej, Wydawnictwo UŚ, Katowice 2016, J. Patel The 'Biological Turn' in History Writing, „Exchanges” 2017 No. 4 (2), s. 280-297. 
zainteresowanie badaniem kulturowych relacji człowieka ze środowiskiem. Wpisuje się w takie interdyscyplinarne obszary badawcze jak studia nad zwierzętami (human-animal studies), historia zwierząt (animal history) ${ }^{3} \mathrm{i}$ historia środowiskowa (environmental history). Moje badania korespondują z pracami zgłębiającymi relacje między tym, co biologiczne, a tym, co polityczne $\mathrm{w}$ XX-wiecznych strategiach modernizacyjnych ${ }^{4}$, oraz podobieństwami między projektami genocydalnymi a niektórymi formami zarządzania środowiskiem ${ }^{5}$. W najszerszym sensie artykuł powinien być rozpatrywany w kontekście procesów „tworzenia Innego” („othering”) i dehumanizacji jako głównych czynników kształtujących strategie genocydalne, które mają swoje odpowiedniki w programach tępienia zwierząt określanych mianem szkodników. Należy wyraźnie podkreślić, że artykuł nie deprecjonuje realnych problemów związanych z obecnością szczurów w otoczeniu człowieka. Bada natomiast, w jaki sposób negatywne zjawiska związane z międzygatunkową kohabitacją (konkurowanie o zasoby, wspólnota patogenów) są przekuwane w schematy narracyjne, odzwierciedlające lęki, uprzedzenia i zespoły przekonań dominujące w danej epoce, a także wpisujące się w określone narracje polityczne.

\section{Deratyzacja a dehumanizacja. Dwa rodzaje degradacji symbolicznej szczura}

Aby zdefiniować czystkę gatunkową jako pojęcie opisujące praktyki tępienia szczurów w PRL, należy najpierw przyjrzeć się zjawisku degradacji symbolicznej, a tym samym moralnej, jednostek będących przedmiotem czystki, jako warunku wstępnego zaistnienia tego zjawiska. W przypadku masowych i przeprowadzanych metodycznie programów eksterminacji ludzi warunkiem takim jest zazwyczaj dehumanizacja jednostek lub grup uznanych za niebezpieczne i zagrażające porządkowi społecznemu. Pojęcie to definiowane jest najczęściej jako odmówienie osobie lub grupie osób człowieczeństwa, bądź

Por. E. Domańska Historia zwierząt, "Konteksty” 2016 nr 3/4.

4 Należy wspomnieć m.in. takie publikacje jak: F. Rowe Davis Banned: A History of Pesticides and the Science of Toxicology, Yale University Press, New Haven 2004; N. Ahuja Bioinsecurities: Disease Interventions, Empire, and the Government of Species, Duke University Press Books, Durham-London 2016 oraz L. Nash Inescapable Ecologies: a History of Environment, Disease, and Knowledge, University of California Press, Berkeley-Los Angeles 2007.

5 Np. A. Franklin An Improper Nature? Introduced Animals and 'Species Cleansing' in Australia, w: Human and Other Animals. Critical Perspectives, ed. by B. Carter, Ch. Nickie, Palgrave 2011; D. Wadiwel The War against Animals (Critical Animal Studies), Brill/Rodopi, Leiden-Boston 2015. 
całkowicie, bądź też w konkretnym obszarze ${ }^{6}$. Pisząc o Holokauście, Zygmunt Bauman zwraca uwagę na charakterystyczną cechę dehumanizacji w ludobójstwie, jaką jest technicyzacja obiektów działań administracyjnych, a więc możliwość określenia ich za pomocą pojęć obojętnych z punktu widzenia etyki ${ }^{7}$. Dehumanizacji towarzyszy przy tym językowa stygmatyzacja „obcego"8. Częstym zjawiskiem jest utożsamienie prawdziwego lub wyobrażonego wroga ze zwierzęciem, zwłaszcza takim, odnośnie do którego istnieją negatywne skojarzenia kulturowe - karaluchem, świnią czy właśnie szczurem.

O ile dehumanizacja stanowi warunek wstępny wystąpienia czystki, zapowiadając ją i dając jej symboliczną podbudowę, o tyle deratyzacja jest samą czystką. Procesy, które ją poprzedzają, są jednak analogiczne do procesów dehumanizacji w programach ludobójstwa, bezpośrednio łączą się bowiem z moralną degradacją zwierząt. W nawiązaniu do figury homo sacer Agambena Robin Mackenzie proponuje figurę bestia sacer, a więc kategorię „podzwierząt”. Włącza do niej określone gatunki lub populacje, których nie obejmuje prawodawstwo określające warunki ich eksploatacji pod względem dobrostanu. Kategoria ta jest przy tym dynamiczna, a poszczególne grupy lub jednostki dostępują w jej ramach symbolicznego wyłączenia ze zwierzęcej wspólnoty w zależności od kontekstu społeczno-ekonomicznego lub środowiskowego, zwłaszcza w przypadku ich szkodliwości ekosystemowej lub przydatności do celów człowieka9. Uważam, że zarysowane tu pojęcie może trafnie opisywać mechanizm symbolicznej degradacji gryzoni w praktykach deratyzacji. Co więcej, w przypadku szczurów ów mechanizm nie objawia się wyłącznie na poziomie legislacyjnym, ale ma wyraźne podłoże kulturowe, w omawianej epoce wzmacniane szerokimi działaniami propagandowymi ${ }^{10}$. Opisywanie

6 S. Oliver Dehumanization: Perceiving the Body as (In)human, w: Humiliation, Degradation, Dehumanization. Human Dignity Violated, ed. by P. Kaufmann i in., Springer, Dordrecht-HeidelbergLondon-New York 2011, s. 86.

7 Z. Bauman Nowoczesność i Zagłada, Fundacja Kulturalna Masada, Warszawa 1992, s. 149.

8 J. Leociak Przedmowa do: M.I. Midlarsky Ludobójstwo wXX wieku, PWN, Warszawa 2010, s. XI.

9 R. Mackenzie How the Politics of Inclusion/Exclusion and the Neuroscience of Dehumanization/ Rehumanization Can Contribute to Animal Activists' Strategies: Bestia Sacer II, "Society \& Animals" 2011 No. 19, s. 407-424.

Szczególnie obfita w materiały do analizy jest dekada 1947-1957, kiedy doszło do niespotykanej wcześniej ani później intensyfikacji zainteresowania tępieniem tego gatunku. Liczba naukowych, popularnonaukowych i poradnikowych publikacji dotyczących zwalczania szczurów, wydanych w ciągu zaledwie tych kilku lat była większa niż ilość analogicznych publikacji wydanych w Polsce kiedykolwiek wcześniej i później, włączając w to czasy po 1989 roku. Szeroko za- 
tępienia tych zwierząt bardziej w kategoriach sanitarnych niż w kategoriach zarządzania środowiskiem, będące konsekwencją i odzwierciedleniem procesu symbolicznego wykluczenia szczura ze wspólnoty kręgowców i jego degradacji do poziomu „podzwierzęcia”, wykazuje analogie z procesami dehumanizacji w programach genocydalnych.

Wyraźne sprzężenie między pojęciami dehumanizacji i deratyzacji ma jednak głębsze podłoże. Jedna z dwóch rozpoznanych przeze mnie strategii degradacji symbolicznej szczurów („szczur jako wróg”) koreluje bowiem wyraźnie z antropomorfizacją tych zwierząt, co można ujmować w kategoriach odwróconego mechanizmu dehumanizacji. W materiałach propagandowych wzywających do tępienia tych ssaków, ale także w debacie naukowej tego okresu można obserwować wyraźne nasilenie języka zabarwionego militarystycznie („śmiertelny wróg rodzaju ludzkiego”,,zawzięta walka”,,,podcięcie podstaw egzystencji”, ,armia szczurów”, ,całkowite wyniszczenie”), zaś grupy ich tępicieli zorganizowane były w hierarchiczne „patrole” $i$ „drużyny”. Utożsamienie szczur-wróg zasadza się na przydaniu temu zwierzęciu pewnych cech ludzkich, ale jedynie w tym celu, żeby tym łatwiej zastosować wobec niego retorykę wojenną, utożsamiając je z kategoriami osób o negatywnych konotacjach kulturowych. Wobec zwierząt stosuje się więc typowo ludzkie kategorie („złodziej”, ,wróg”) i przypisuje cechy tradycyjnie łączone z Homo sapiens („przebiegły”, „złośliwy”, ,zuchwały”). Szczury zostają więc symbolicznie włączone do kulturowej wspólnoty, jednak tylko po to, żeby mógł zaistnieć proces przypisania im negatywnych konotacji.

Antropomorfizację w propagandzie deratyzacyjnej można zatem traktować jako pozorną nobilitację. Nobilitację, ponieważ symbolicznie przydaje szczurom cech łączonych z człowiekiem. Pozorną, gdyż jej właściwym celem jest moralna degradacja przeciwnika. Antropomorfizacja w deratyzacji staje się tym samym dehumanizacją à rebours. Podobnie bowiem jak w strategiach dehumanizacji, wykluczone jednostki ludzkie są przyrównywane do zwierząt, tak w strategiach moralnej deprecjacji towarzyszącej praktykom deratyzacyjnym, szczury przyrównuje się do ludzkich wrogów. W obu przypadkach mamy do czynienia z symbolicznym wyłączeniem danej grupy z ludzkiej/

krojona akcja edukacyjno-propagandowa, obejmująca m.in. plakaty, ulotki, pogadanki, zamawiane materiały prasowe i audycje radiowe, umożliwiła dotarcie do ludności z komunikatem o konieczności tępienia szczurów. Tak rozbudowana i konsekwentnie realizowana kampania była możliwa dzięki daleko idącej centralizacji tej branży, która odtąd nazywana będzie „służbą DDD". 
zwierzęcej populacji i stworzenie „stanu wyjątku” (state of exception ${ }^{11}$ ) umożliwiającego zawieszenie wątpliwości i sądów moralnych. Zdegradowanym moralnie grupom symbolicznie odbierana jest ich specyfika, zastępowana statusem wyobrażonym, w którym są one nośnikami najgorszych cech przypisywanych drugiej stronie. Proces ten ma na celu podkreślenie ich inności i monstrualności, co jest warunkiem brzegowym dla uznania ich za jednostki pozbawione wartości, a w efekcie, godne bezwzględnej eksterminacji. Kluczowym momentem jest tu mechanizm wyłączenia ze wspólnoty. W logice ludobójczej ludzki, ale symbolicznie zdehumanizowany wróg nie jest w pełni człowiekiem, nie ma więc wartości moralnej. Zoomorfizm ma zatem podkreślić symboliczne zerwanie z ludzką wspólnotą. W programach deratyzacyjnych szczur nie jest natomiast do końca zwierzęciem, nie ma bowiem dla człowieka wartości ani sentymentalnej, ani utylitarnej, ani ekologicznej. Jest w tej narracji odrębnym bytem: śmiertelnym przeciwnikiem człowieka, szkodnikiem, „podzwierzęciem”. Antropomorfizacja ma podkreślać owo zerwanie ze światem zwierzęcym i wypełnić figurę szczura nowym znaczeniem: fantazmatem wroga.

O ile paradoksalną strategię „deprecjonującej antropomorfizacji” można obserwować głównie w narracji militarystycznej, o tyle druga strategia deprecjacji szczura obserwowana w propagandzie deratyzacyjnej charakterystyczna jest dla narracji sanitarno-epidemiologicznej. Szczur w tej narracji zostaje pozbawiony swojej zwierzęcej specyfiki i symbolicznie zrównany z patogenami, które przenosi. Połączenie w ramach jednego pojęcia („DDD”) tępienia szczurów, insektów i drobnoustrojów symbolicznie wyłącza tego ssaka z kategorii przyrody, włączając go w narrację sanitarną, opisującą go jako niebezpieczny brud i odpad. Eliminacja szczurzych populacji staje się tym samym formą oczyszczenia danego obszaru z elementu niepożądanego. Pozbawianie zwierząt życia określane bywa eufemistycznie jako „zespół czynności", wizualnie przedstawiane przy użyciu wykresów, tabel i infografik.

Mamy tu do czynienia z odwrotną strategią, co w przypadku antropomorfizacji. Zrównanie z patogenami nie jest bowiem nawet pozorną nobilitacją. Wykazujące się wysokimi zdolnościami kognitywnymi zwierzę zostaje bowiem symbolicznie identyfikowane z jednostką chorobową. W przeciwieństwie do strategii antropomorfizacyjnej owo zrównanie rzadko bywa wyrażane explicite. Tego rodzaju postrzeganie szczura stanowi bowiem nie tyle celowo przyjmowaną strategię propagandową, co nie do końca świadomy mechanizm

11 A. Mbembe Necropolitics, „Public Culture” 2003 No. 15 (1), S. 11-40. 
mentalny organizujący okołoderatyzacyjne praktyki dyskursywne, będący konsekwencją ustanowienia pojęcia DDD. Włączenie szczurów do narracji sanitarnej funduje nowy konglomerat pojęciowy organizujący zbiorową wyobraźnię na temat tych zwierząt, bazujący na ich metonimicznym zespoleniu z jednostkami chorobowymi. Szczury nie są już po prostu nielubianymi zwierzętami (którymi były od stuleci), stają się natomiast odcieleśnionym problemem do rozwiązania, włączonym w zbiurokratyzowany system praktyk sanitarno-epidemiologicznych i ,skutecznie odgrodzonym od ludzkiej wspólnoty ścianą wstrętu"12. Podobnie jak w definicji Baumana, zostają „zredukowane do zespołu mierników ilościowych"13, a ich śmierć liczona jest w kilogramach zebranych ciał, metrach kwadratowych lub ilościach ton zużytej trutki. Należy przy tym zaznaczyć, że dwie zarysowane wyżej strategie degradacji nie są rozłączne; przeciwnie, nierzadko występują ze sobą w wyraźnej korelacji. Część analizowanych materiałów przedstawia szczura jako wroga będącego zarazem wektorem choroby, co wzmacnia emocjonalną wymowę komunikatu.

Należy jednak wskazać zasadniczą różnicę między tymi strategiami degradacji w programach genocydalnych i deratyzacyjnych. W procesie dehumanizacji mamy bowiem do czynienia z symbolicznym wyłączeniem z ludzkiej wspólnoty określonych jednostek i grup. W strategiach towarzyszących moralnej deprecjacji szczurów w retoryce deratyzacyjnej występuje natomiast zjawisko symbolicznego wyłączenia całego gatunku ze zwierzęcej wspólnoty. W narracji militarystycznej staje się on „czymś więcej” niż zwierzę, zostaje bowiem symbolicznie zdefiniowany jako zantropomorfizowany wróg gatunku ludzkiego. W narracji sanitarnej staje się natomiast „czymś mniej”, zdegradowany do patogenu i problemu natury technicznej. W obu jednak przypadkach na poziomie dyskursywnym przestaje funkcjonować jako zwierzę. Symbolicznej degradacji i wykluczenia ze zwierzęcej wspólnoty doznaje zatem nie określona populacja, ale cały gatunek. Wezwania do „całkowitego wytępienia” i podkreślanie niebezpieczeństwa, które może stworzyć „każdy pozostały przy życiu szczur", wyraźnie wskazują na dążenia anihilacyjne, nawet jeśli zdawano sobie sprawę, że całkowita likwidacja tego gatunku jest w praktyce niemożliwa ${ }^{14}$.

P. Krupiński „Dlaczego gęsi krzyczały?" Zwierzęta i Zagłada w literaturze polskiej XX i XXI wieku, Wydawnictwo IBL PAN, Warszawa 2016, s. 77.

14 Aczkolwiek dążenia anihilacyjne są żywe także współcześnie. Na przykład Nowa Zelandia podjęła uchwałę o całkowitym wytępieniu szczurów, uznanych za gatunek inwazyjny, do 2040 


\section{Szczur jako Żyd i szkodnik społeczny. Mechanizmy czystki etnicznej i politycznej w retoryce deratyzacyjnej}

W warstwie ikonograficznej przedstawienia szczura wykazują wyraźne podobieństwa z retoryką opisującą jednostki i grupy, które w XX-wiecznych narracjach totalitarnych zostały poddane procesowi moralnej deprecjacji i dehumanizacji, będącej wstępem bądź do zjawiska ludobójstwa, bądź innej formy ich wykluczenia z politycznej wspólnoty. Uważam, że wykazują one wyraźne strukturalne analogie zarówno z "sanitarnymi” metaforami pojawiającymi się w czystkach o charakterze etnicznym, jak i z militarystyczno-obywatelską frazeologią towarzyszącą czystkom politycznym. Spróbuję wykazać, że te dwa schematy narracyjne uległy specyficznemu scaleniu w retoryce opisującej szczura, zwłaszcza w propagandzie lat 50.

W retoryce deratyzacyjnej mamy do czynienia z trwałością motywów ikonograficznych i kalek językowych związanych z retoryką antysemicką, posiadającą jeszcze przedwojenną lub wojenną genezę. Powszechnie wiadomo, że w nazistowskiej propagandzie Żydzi byli często przedstawiani jako szczury, a wielu badaczy zwraca uwagę na ekologiczny wymiar projektu, jakim był Holokaust ${ }^{15}$. Proponuję przyjrzeć się dwóm przedstawieniom sprzed 1945 roku, wykazującym wyraźne sprzężenie między retoryką antysemicką a deratyzacyjną. Pierwszym jest okładka pisma "Rozwój” z 1925 roku, z ilustracją Bogdana Nowakowskiego ukazującą gromadę szczurów uciekającą w popłochu przed ubranym w mundur mężczyzną, wypłaszającym je z domu miotaczami ognia. Godło orła na drzwiach sugeruje, że ukazany na przedstawieniu budynek ma symbolizować Polskę. Dopiero bliższe prześledzenie ilustracji pozwala stwierdzić, że szczury posiadają atrybuty przypisywane Żydom: pejsy, stereotypowo żydowską fizjonomię oraz gwiazdy Dawida na czapkach. Mamy tu więc do czynienia z przedstawieniem „deratyzacji”, ale deratyzacji szczególnej, obiektem eksterminacji są bowiem Żydzi, zdehumanizowani i przedstawieni jako nielubiane gryzonie. Retoryka tępienia szkodników zostaje tym samym scalona z retoryką polityczną, podobnie jak w propagandzie nazistowskiej, traktującej Żydów jako niebezpieczne, brudne

roku. Motywowane jest to ich szkodliwością ekologiczną, zwłaszcza zagrożeniem, jakie niosą dla endemicznych gatunków zwierząt, https://www.theguardian.com/world/2016/jul/25/nomore-rats-new-zealand-to-exterminate-all-introduced-predators (15.02.18).

15 Por. Z. Bauman Nowoczesność i Zagłada; B. Neumann National Socialism, Holocaust and Ecology, w: Holocaust and Historical Methodology, ed. by D. Stone, Berghahn Books, New York-Oxford 2012. 
zwierzęta, których należy się pozbyć w procesie budowy nowoczesnego narodu. Eksterminacja szczurów-Żydów jest tu przedstawiana jako oczyszczanie domu-Polski z osobników niepożądanych, jako dosłowne wygnanie ich za próg domu (ex termino). Kolejnego przykładu na scalenie retoryki antysemickiej i deratyzacyjnej może dostarczyć niedatowany, ale pochodzący prawdopodobnie z czasów II wojny światowej, plakat reklamujący trutkę Delicia. Przedstawia on, dosyć realistycznie, dwa szczury, choć realizm przedstawienia jest wyraźnie naruszony nienaturalnymi, czerwonymi źrenicami zwierząt. Bardziej interesująca niż samo przedstawienie szczurów jest jednak stylistyka pozostałych elementów graficznych plakatu. Jego kolorystyka, a zwłaszcza charakterystyczna typografia, jawnie powiela bowiem estetykę nazistowską. Choć odwołania antysemickie nie są tu tak ewidentne, jak na poprzednim przedstawieniu, scalenie tępienia szczurów z estetyką hitlerowską może generować jednoznaczne skojarzenia. Jego komplementarność wobec ryciny z 1925 roku zasadza się przy tym na ich retorycznym przeciwieństwie. O ile ta pierwsza wykorzystuje schematy narracyjne związane ze zwalczaniem szczurów dla wyrażenia treści o charakterze antysemickim, o tyle plakat Delicji nawiązuje do nazistowskiej stylistyki w celu przeszczepienia logiki eksterminacyjnej (i towarzyszących jej emocji) na tępienie zwierząt. Mamy tu więc do czynienia $\mathrm{z}$ wizualnym amalgamatem scalającym narrację antysemicką i deratyzacyjną.

Powojenna propaganda deratyzacyjna wyrasta więc na gruncie, w którym figura szczura i Żyda są ze sobą mocno splecione. Nawet jeśli tego rodzaju treści nie są w niej wykorzystywane świadomie, bazują one na utartych kliszach wypracowanych w dwudziestoleciu międzywojennym i w czasach okupacji. Moja teza nie zakłada przy tym, że przedstawienia szczura w propagandzie stalinowskiej były ukrytymi przedstawieniami o charakterze antysemickim, ale że na poziomie ikonograficzno-językowym stanowią częściowe przejęcie motywów i struktur wypracowanych w retoryce rasistowskiej. Mam tu na myśli m.in. takie wątki jak przedstawienie szczura jako złodzieja i zagrożenie dla gospodarki narodowej, zagrożenie epidemiologiczne czy silna ambiwalencja (a czasem niekryty podziw), z jaką ukazywano te zwierzęta. Te analogie mogą dzisiaj być już mało czytelne, uważam jednak, że były zrozumiałe dla przeciętnego odbiorcy propagandy deratyzacyjnej zaledwie kilka lat po wojnie.

Drugą ważną tradycją językowo-ikonograficzną, która ukształtowała ramy dla frazeologii propagandy deratyzacyjnej po wojnie, była figura wroga w propagandzie stalinowskiej. Uważam, że ten trop stanowi ważny kontekst dla 
zrozumienia specyfiki relacji między tym, co polityczne, a tym, co biologiczne w powojennej retoryce deratyzacyjnej. $\mathrm{O}$ ile bowiem strategia przedstawiania wrogów politycznych jako szkodników w systemach totalitarnych jest zjawiskiem powszechnie rozpoznanym, o tyle bilateralność tego zjawiska uchodziła dotąd uwagi badaczy.

Retoryka określająca szczura jako wroga była wyraźnie zakorzeniona $\mathrm{w}$ fantazmacie wroga politycznego, powszechnym w polskiej propagandzie lat 50. Fantazmat ten miał w stalinizmie określoną funkcję: mianowicie umożliwiał mobilizację społeczną wobec prawdziwych lub wykreowanych zagrożeń, był także wykorzystywany dla usprawiedliwiania niepopularnych decyzji ekonomicznych i politycznych, tłumacząc niepowodzenia w różnych dziedzinach życia ${ }^{16}$. W propagandzie czasów PRL chętnie wykorzystywana była zwłaszcza terminologia wojskowa, pojawiało się w niej zatem wiele pojęć o wyraźnie militarnym zabarwieniu, przy czym słowo „walka” stosowano w odniesieniu do nawet najbardziej trywialnych spraw ${ }^{17}$. Wróg w tej narracji był łatwo rozpoznawalny, odznaczał się bowiem odrażającymi cechami fizycznymi, które odzwierciedlały negatywne cechy jego charakteru. Szczególnie ważne w kontekście moich rozważań jest to, że obrazowi wroga często towarzyszyła jego dehumanizacja wyrażana przez zoomorfizm, a więc przypisywanie jego wyglądowi i zachowaniom cech właściwych zwierzętom, zwłaszcza tym posiadającym niski status kulturowy, co miało podkreślić jego inność i symbolicznie przeciwstawić społeczności'i

Ważnym zjawiskiem dla zrozumienia specyfiki spajania narracji biologicznej z polityczną w stalinowskiej propagandzie deratyzacyjnej jest popularne wówczas pojęcie szkodnika społecznego. Mimo zróżnicowanej formy liczby mnogiej tego słowa (szkodniki/szkodnicy) mamy tu do czynienia z wyraźnym sprzężeniem pojęciowym, wyrażającym dążenie do dehumanizacji osób cechujących się określonymi, negatywnie postrzeganymi cechami. Szkodnikami określane były jednostki, które z niedbałości, egoizmu lub poduszczenia wrogów systemu dopuszczały się działań na szkodę społeczną,

16 J. Wojsław Obraz teraźniejszości w propagandzie komunistycznej Polski lat 1949-1954. Zarys problematyki, Wydawnictwo Uniwersytetu Gdańskiego, Gdańsk 2009, s. 42.

17 M. Czyżniewski Propaganda polityczna władzy ludowej w Polsce 1944-1956, Wydawnictwo Naukowe Grado, Toruń 2005, s. 174.

18 J. Smulski Wróg klasowy jako „obcy” w polskiej literaturze socrealistycznej, w: Od Szczecina do... Października. Studia o literaturze polskiej lat pięćdziesiq̨tych, red. J. Smulski, Wydawnictwo Uniwersytetu Mikołaja Kopernika, Toruń 2002, s. 83-84. 
np. strat w gospodarce narodowej. Działaniom takim przypisywano przy tym złośliwość i celowe złe intencje, mające na celu sabotaż systemu. Szkodnikiem mógł być złodziej, kułak czy kłusownik, choć czasem jego tożsamość jest zacierana $\mathrm{w}$ warstwie wizualnej i równocześnie tworzy pojemną kategorię, która mogła być wypełniona przez doraźnie dobrane negatywne postawy społeczne. W warstwie wizualnej szkodnik społeczny jest często dehumanizowany, przedstawiany na podobieństwo nielubianych zwierząt.

Wartym odnotowania przykładem przeszczepienia motywu szczura w obszar propagandy politycznej jest plakat Włodzimierza Zakrzewskiego z 1945 roku. Przedstawia on szczura podgryzającego fundamenty domu, co uzupełnione jest napisem: „Demokracja buduje, reakcja chce szkodzić”. Siły reakcji przedstawione są tutaj jako gryzoń niszczący świeżo wzniesione fundamenty nowego systemu. Choć pojęcie szkodnika nie pojawia się w warstwie językowej, głębokie zakorzenienie archetypu szczura-szkodnika sprawia, że przedstawienie jest całkowicie czytelne dla potencjalnego widza. Jeśli zestawimy ten plakat z propagandowymi materiałami deratyzacyjnymi, zauważymy, że zachodzi tu interesujące zjawisko. O ile te pierwsze wykorzystują stereotyp wroga, żeby zachęcać do tępienia szczurów, o tyle to przedstawienie robi coś dokładnie odwrotnego: odwołuje się do negatywnego stereotypu szczura-szkodnika po to, żeby wyrazić moralne potępienie wobec szkodników społecznych. Podobnie jak w przedstawieniach powielających treści antysemickie, mamy więc do czynienia z charakterystycznym sprzężeniem zwrotnym. Metafora działa tu w dwie strony: szczur jest jak Żyd/szkodnik społeczny/ wróg, ale zarazem Żyd/szkodnik społeczny/wróg jest jak szczur. Trudno przy tym wskazać w tak skonstruowanym komunikacie metaforę źródłową. Wydaje się, że na głębszym poziomie jest on ufundowany na powszechnych kulturowych schematach wykluczenia, w ramach których jednostka lub grupa stojąca nisko w hierarchii symbolicznej jest porównywana do jednostki lub grupy, która w danym kontekście historyczno-kulturowym stoi w hierarchii jeszcze niżej. Konstruowanie owych hierarchii jest przy tym procesem dynamicznym, uwarunkowanym przez kontekst kulturowy oraz cele i specyfikę konkretnej wypowiedzi o charakterze propagandowym. Dlatego degradacja określonej grupy ludzi poprzez ukazywanie ich pod postacią szczurów może występować jednocześnie z przeciwstawną retoryką, degradującą zwierzęta poprzez ich zantropomorfizowanie i wpisanie w figurę wroga.

Figury Żyda w propagandzie nazistowskiej i wroga w stalinizmie mają wiele wspólnych cech. Można wśród nich wymienić dehumanizację jednostek należących do danej grupy, przekonanie, że działają one na szkodę 
społeczeństwa/narodu, czy wreszcie ich silne powiązanie z narracją sanitarną wraz z towarzyszącą im metaforą oczyszczania. Na wstępie postanowiłam wyraźnie rozgraniczyć te narracje, aby uwydatnić charakteryzujące je różnice. O ile bowiem w narracji nazistowskiej eksterminacja Żydów miała wyraźne podłoże biologiczne (była, by znów przywołać Baumana, „pieleniem chwastów"19), o tyle retoryka czystek stalinowskich opierała się na logice polityczności, w której wroga tworzyła nie tyle jego etniczność, ale stosunek do systemu. Retorykę Holokaustową można więc włączyć w mechanizm czystki etnicznej, zaś retoryka stalinowska spełnia kryteria czystki o charakterze politycznym. Uważam jednak, że w przypadku propagandy deratyzacyjnej te dwie narracje uległy daleko idącemu stopieniu na poziomie retorycznym. Tępienie szczurów jest operacją o charakterze biologicznym, opartą na kryterium gatunkowym, a więc quasi-etniczną. Zwalczaniu nie podlega bowiem określona populacja szczurów, która osiągnęła poziom krytyczny i stała się przez to potencjalnie niebezpieczna dla otoczenia, ale szczury w ogóle. Retoryka wzywająca do tępienia tych zwierząt wyraża jawne tendencje anihilacyjne, a ich szkodliwość funkcjonuje w jej ramach jako coś wrodzonego, nieodzownego z powodu samej ich przynależności do określonego gatunku. Zarazem jednak przedstawienia szczurów w jawny sposób powielają schematy retoryczne wykorzystywane do opisywania wrogów systemu w propagandzie stalinowskiej. Militarystyczna retoryka i sprzężenie z figurą szkodnika społecznego dają podstawy do wysnucia tezy, że mamy do czynienia z czymś więcej niż jedynie analogią. W propagandzie stalinowskiej szczur nie tylko przypomina wroga politycznego, ale niemal dosłownie się nim staje, przejmując zawartość semantyczną przedstawień propagandowych o charakterze politycznym. Retoryka deratyzacyjna stanowi więc podwójne przywłaszczenie: z jednej strony genocydalnej, , higienicznej" narracji antysemickiej, z drugiej natomiast - bazującej na figurze wroga czystki politycznej, powszechnej w propagandzie stalinowskiej.

\section{Czystka gatunkowa jako militarystyczny wymiar modernizacji}

Mianem czystki gatunkowej można więc określić program metodycznej eksterminacji zwierząt opartej na kryterium gatunkowym z towarzyszącą mu wyraźnie anihilacyjną frazeologią oraz silną mobilizacją społeczną. W przypadku materiałów powstałych w czasach stalinowskich była ona 
wizualizowana za pomocą analogicznych strategii retorycznych, jakie wykorzystywano w programach eksterminacji ludzi: symbolicznego wyłączenia ze wspólnoty, przypisywania kolektywnej winy za problemy i niepowodzenia społeczności (mechanizm kozła ofiarnego) i zagrzewania odbiorców do aktywnego, entuzjastycznego włączenia się w akcje ich tępienia. Symboliczny status "podzwierzęcia" podbudowany był przy tym logiką bazującą na kulturowych schematach nieczystości i oczyszczania. Logika ta ma oczywiście swoją głęboką podbudowę kulturową i bazuje na rozumieniu brudu zaproponowanym przez Mary Douglas, a więc jako zaburzenia porządku społeczne$\mathrm{go}^{20} \mathrm{i}$ czegoś nie na swoim miejscu ${ }^{21}$. Jednak zaistnienie mechanizmu czystki gatunkowej możliwe było dopiero w efekcie pojawienia się naukowej, sanitarnej nadbudowy dla tego zjawiska sprawiającego, że zwierzęta te zostają w pełni włączone w „higieniczne” praktyki dyskursywne. Rozpoznanie wspomnianego wcześniej podwójnego przywłaszczenia retorycznego nie oznacza przy tym, że w deratyzacyjnej propagandzie i towarzyszącym jej dwóm strategiom wykluczenia mamy do czynienia z prostym podobieństwem do czystek etnicznych i politycznych. Innymi słowy, uproszczeniem byłaby teza, że strategia „szczur jako patogen”, jako towarzysząca „higienicznej” retoryce czystki etnicznej, jest wyłączną spuścizną narracji antysemickiej, zaś strategia „szczur jako wróg” odbija wyłącznie polityczną narrację wykluczenia czasów stalinowskich. W rzeczywistości relacje między nimi są bardziej skomplikowane.

Scalenie dyskursu militarystycznego z sanitarno-epidemiologicznym nie występuje jedynie w kontekście tępienia szczurów. Susan Sontag zwraca uwagę, że w debatach dotyczących chorób powszechnie stosuje się militarystyczne metafory, takie jak „inwazja” choroby czy "mechanizm obronny” organizmu. Badaczka zauważa, że podstawowe metafory stosowane w opisach raka wywodzą się bezpośrednio z języka wojskowego. Podobnie militarny posmak mają opisy leczenia: radioterapia posługuje się metaforami wojny powietrznej, w ramach której pacjentów „bombarduje się” zabójczymi promieniami, zaś chemioterapia to wojna chemiczna z użyciem trucizn ${ }^{22}$. W efekcie włączenia zwierząt mogących przenosić choroby w narrację sanitarną retoryka towarzysząca ich tępieniu zaczyna posługiwać się podobną

M. Douglas Czystość i zmaza, PIW, Warszawa 2007, s. 46.

Tamże, s. 77. 
logiką. Jako ucieleśnienie choroby tzw. szkodnik sanitarny staje się obiektem praktyk, które na wielu poziomach powielają mechanizmy działań wojennych. Analizując praktyki dezynsekcyjne i operacje wojskowe prowadzone za pomocą broni chemicznej w XX wieku, Edmund Russell wskazuje na ich daleko idącą komplementarność: począwszy od poziomu propagandowego, poprzez instytucjonalny, skończywszy na stosowanych metodach. Wyraźnie podkreśla tym samym, że owe analogie idą w dwie strony: wojna z wrogiem przedstawiana jest jako wojna ze szkodnikami, zaś wojnę ze szkodnikami konceptualizuje się w taki sam sposób, jak wojnę z wrogiem² ${ }^{23}$. Jak wykazałam, taka retoryczna dwubiegunowość występuje także w polskim dyskursie dotyczącym tępienia wrogów i szkodników.

Uważam, że zjawisko to można traktować jako odzwierciedlenie szerszego mechanizmu związanego z dynamiką procesów modernizacji, zwłaszcza w ich socjalistycznym wcieleniu. Już pobieżny przegląd polskich druków propagandowych z lat 1945-1957 pokazuje, że metafory „oczyszczenia” są powszechnie używane w kontekście walki z faszyzmem, spekulantami, szkodnikami społecznymi i innymi zjawiskami odbieranymi jako negatywne. Język sanitarno-modernizacyjny jest tu zatem wyraźnie sprzężony $\mathrm{z}$ retoryką militarystyczną. Plakaty nie precyzują, czym w praktyce miałoby być owo „oczyszczenie" kraju z wrogów - czy chodzi o ich ukaranie, czy eksterminację. Pozbycie się jednostek niepożądanych ukazane jest tu jednak za pomocą metafor o charakterze sanitarnym, co przypomina genocydalny język powszechny w propagandzie nazistowskiej.

Scalenie narracji wojennej i sanitarnej w propagandzie stalinowskiej nie jest zatem cechą właściwą jedynie dyskursowi deratyzacyjnemu, choć w nim właśnie objawiło się w najbardziej dosadny sposób. Może to być spowodowane faktem, że w propagandzie stalinowskiej dominowała narracja o przyrodzie jako silnie antymodernistycznym żywiole, który należy ujarzmić i wykorzystać w imię postępu. W tej retoryce środowisko przyrodnicze było nagminnie konceptualizowane jako groźny przeciwnik, pozostałość przedrewolucyjnej przeszłości, opierające się socjalistycznej industrializacji. Dlatego w opisach zmagania się człowieka z przyrodą często sięgano po militarystyczną retorykę, w celu mobilizacji społeczeństwa i wyrobienia w nim poczucia zagrożenia. Jak zauważa Filip Gończyński-Jussis, natura stawała się kolejnym, po Trzeciej Rzeszy, wrogiem społeczeństwa socjalistycznego, którego

23 E. Russell War and Nature. Fighting Humans and Insects with Chemicals from World War I to Silent Spring, Cambridge University Press, Cambridge 2011, s. 99. 
pokonanie było możliwe jedynie drogą bezwarunkowej kapitulacji ${ }^{24}$. Staje się więc zrozumiałe, że szczury, zwierzęta o tak negatywnych konotacjach kulturowych, a zarazem poprzez swój tryb życia wyłamujące się z reżimu modernizacji, dostarczyły użytecznego modelu dla figury wroga. W tej logice zamieszkałe przez nie tereny zaczynają być postrzegane jako zacofane i wsteczne, zaś proces odbudowy i modernizacji miast opiera się na założeniu, że powinny być one wolne od szczurów. Socjalizm rozumiany jako modernizacja staje się zatem socjalizmem walczącym ze szczurem - synonimem biedy, chorób, wojennych zniszczeń i sanacyjnego zacofania. Parafrazując słowa Baumana o ludobójstwie, można powiedzieć, że zabijanie tych zwierząt nie było aktem destrukcji, ale aktem tworzenia - lepszego, zdrowszego i nowocześniejszego społeczeństwa ${ }^{25}$. Jako gatunek stanowiący zagrożenie zarówno sanitarne (wektor chorób zakaźnych), jak i ekonomiczne („złodziej” plonów) szczur może być postrzegany jako ucieleśnienie wyzwań, z którymi musiało konfrontować się polskie państwo w czasach powojennej odbudowy. Dynamika powojennych programów tępienia szczurów może być zatem rozpatrywana w kategoriach permanentnego ścierania się tego, co ludzkie, z tym, co nie-ludzkie, (tudzież biologicznego z kulturowym) w procesie modernistycznej "puryfikacji”26 i jako taka może rzucić nowe światło na dynamikę procesów modernizacyjnych w powojennej Polsce.

Należy mieć jednak na względzie, że scalenie języka militarystycznego z sanitarnym w ówczesnym dyskursie środowiskowym nie jest jednak wyłączną specyfiką bloku wschodniego i wymaga uwzględnienia szerszego kontekstu związanego z procesami modernizacji. W połowie XX wieku nastąpił bowiem wyraźny wzrost konfrontacyjnego, przemocowego języka używanego do opisu relacji między człowiekiem a środowiskiem. Zjawisko to dotyczyło także krajów po drugiej strony żelaznej kurtyny, zwłaszcza Stanów Zjednoczonych. Lata 40.i 50. wyznaczają szczyt popularności używanych bez umiaru pestycydów i wiary w to, że człowiek może całkowicie podporządkować sobie przyrodę ${ }^{27}$. Z procesem tym współwystępowały takie zjawiska jak początki

24 F. Gończyński-Jussis „Przeobraziciele przyrody”. Motyw kształtowania środowiska naturalnego przez „ludzi radzieckich" $i$ ich polskich naśladowców w propagandzie stalinizmu, „Historyka. Studia metodologiczne" $2016 \mathrm{nr} 46$.

B. Latour Nigdy nie byliśmy nowocześni. Studium z antropologii syntetycznej, przeł. M. Gdula, Oficyna Naukowa, Warszawa 2011. 
hodowli przemysłowej zwierząt i intensywny rozwój badań laboratoryjnych z ich udziałem (z których część bywa dziś określana jako wątpliwa nie tylko etycznie, ale i poznawczo). Wtedy także narodziło się pojęcie ekologii inwazji, opisujące relacje ekosystemowe w kategoriach militarystycznych. Neel Ahuja zauważa z kolei, że zjawisko zarządzania gatunkami mogącymi przenosić niebezpieczne patogeny, rozumiane jako zarządzanie ryzykiem biologicznym, w XX-wiecznej polityce amerykańskiej wyraźnie koresponduje z procesem ekspansji terytorialnej i ekonomicznej tego kraju ${ }^{28}$. Wszystkie te zjawiska wydają się konsekwencją charakterystycznego dla tej epoki zespołu przekonań, w ramach którego dominacja człowieka nad przyrodą, często wyrażona za pomocą wojennej symboliki, staje się narzędziem modernizacji i postępu. Wzrost zainteresowania tematyką tępienia szczurów w latach 40. (także w USA) można traktować jako naturalną konsekwencję tego zjawiska. Dla obu stron żelaznej kurtyny wspólny jest także militarystyczny rys towarzyszącej tępieniu szczurów propagandy. Lianne McTavish i Jingjing Zheng dowodzą, że programy tępienia szczurów w Albercie w latach 50., podobnie jak stalinowskie programy w Polsce, opierały się na wykreowaniu figury wroga na bazie obrazu szczura. Wykazywały tym samym wyraźne zespolenie z retoryką zimnowojenną, zaś ich warstwa wizualna jawnie nawiązywała do amerykańskiej propagandy z czasów II wojny światowej, kiedy to Japończycy przedstawiani byli jako szczury ${ }^{29}$.

Konfrontacyjna retoryka używana do opisywania tępienia szczurów w czasach stalinowskich jest więc konsekwencją kilku współwystępujących czynników. Na podstawowym poziomie stanowi efekt brutalizacji języka debaty publicznej w tym okresie, operującej figurą wroga i nadużywającej militarnych analogii. W szerszym kontekście stanowi konsekwencję radzieckiego ujmowania przyrody w kategoriach militarystycznych, a także powszechności wizualno-językowych klisz o przedwojennej i wojennej genezie, z których co najmniej część ma wyraźnie rasistowskie proweniencje. W kontekście najszerszym wydaje się natomiast wyraźnie zakotwiczona w specyficznym etapie rozwoju modernistycznej aksjologii, owocującym powszechnym w tej epoce konfrontacyjnym podejściem do przyrody i przekonaniu o możliwości jej całkowitego podporządkowania człowiekowi. Można podejrzewać, że za tym zjawiskiem stała z jednej strony ogólna brutalizacja języka debaty

28 N. Ahuja Bioinsecurities: Disease Interventions, Empire and the Government of Species.

29 L. McTavish, J. Zheng Rats in Alberta: Looking at Pest-Control Posters from the 1950s, "Canadian Historical Review" 2011 No. 92 (3). 
publicznej będąca konsekwencją dwóch wojen światowych, a następnie zimnej wojny, z drugiej zaś postęp naukowy, rodzący nadzieję, że nowe, „cudowne" środki tępienia szkodliwych organizmów (takie jak DDT czy Antu) pozwolą na całkowite wyzwolenie człowieka z ograniczeń narzuconych przez środowisko. Intensyfikacja programów tępienia szczurów w powojennej Polsce oraz towarzysząca im sanitarno-militarystyczna retoryka stanowią zatem odbicie szczególnego etapu rozwoju nowoczesności, kiedy to będąca wojennym pokłosiem konfrontacyjna frazeologia uległa sprzężeniu z dyskursem sanitarno-modernizacyjnym. W Stanach Zjednoczonych powolny odwrót od tej narracji można obserwować od końca lat 50., a za moment przełomowy w procesie stopniowej zmiany retoryki na temat relacji człowieka ze środowiskiem uznaje się zazwyczaj publikację Cichej wiosny Rachel Carson. W Polsce podobna zmiana języka podyktowana była przekształceniami politycznymi po Odwilży. O ile jednak figura szczura-wroga znika z deratyzacyjnej propagandy wraz ze stalinizmem, o tyle figura szczura-patogenu kształtuje percepcję tego zwierzęcia aż do dnia dzisiejszego. 


\section{Abstract}

\section{Gabriela Jarzębowska}

UNIVERSITY OFWARSAW

The Rhetoric of Rat Extermination in the Polish People's Republic: From Ethnic and Political Cleansing to Species Cleansing

Jarzębowska examines the rhetoric used to legitimize the extermination of rats in the era of Socialist Realism. Propaganda materials on rat extermination from 1945 until 1989 reveal analogies with the 'sanitary' metaphors that appeared in the context of (antiSemitic) ethnic cleansing as well as with the phraseology of political cleansing campaigns, which drew on military and civil discourses. Jarzębowska proposes the concept of species cleansing to describe the programme of this methodical extermination of animals. This programme was based on the criterion of the species; it clearly employed the phraseology of annihilation, and it was accompanied by a remarkable collective mobilization.

\section{Keywords}

species cleansing, rats, animals, animal studies, dehumanization, Stalinism 